\title{
Which site is more painful in intramuscular injections? The dorsogluteal site or the ventrogluteal site? A case study from Turkey
}

\author{
Ülkü Yapucu Güneş ${ }^{1}$, Dilek Kara ${ }^{2}$, Suer Arı ${ }^{3}$, Onur Ceyhan ${ }^{3}$ \\ 1. Department of Basic Nursing, Faculty of Nursing Ege University, Izmır, Turkey. 2. Department of Nursing, School of \\ Health, Uludag University, Bursa, Turkey. 3. Department of Brain Surgery Clinic, Cekirge State Hospital, Bursa, Turkey.
}

Correspondence: Ülkü Yapucu Güneş. Address: Department of Basic Nursing, Faculty of Nursing, Ege University. 35040 Bornova/ İzmir, Turkey. Email: ulku.gunes@ege.edu.tr

Received: May 2, 2013

DOI: $10.5430 / c n s . v 1 n 4 p 74$
Accepted: September 4, 2013

URL: http://dx.doi.org/10.5430/cns.v1n4p74

\section{Abstract}

The aim of the study was to examine the effect on pain of medication administered by intramuscular injection to the dorsogluteal and ventrogluteal sites, and to investigate gender and body mass index differences in pain perception between the sites. This clinical trial was performed on 70 adult patients receiving at least two doses of diclofenac sodium intramuscularly in a state hospital in Bursa, Turkey. Two injections were administered to each patient with an interval of 24 hours by the same researcher using two injection sites. The injection sites were randomly allocated. After each injection, the pain felt by patients during the injection was immediately assessed using a visual analog scale by another researcher who had no prior knowledge of which the injection site. Numerical and percentage distribution of sociodemographic data on patients' identification characteristics were calculated. The Wilcoxon signed rank test was used to explore determine the statistical differences in perceived pain intensity between the two injection sites. Differences in the mean pain intensity at the dorsogluteal and ventrogluteal sites by BMI and gender were analysed using the paired t test. The average pain score of patients after injections to the ventrogluteal site was $1.24 \pm 1.18$, while that for injections to the dorsogluteal site was $1.89 \pm 1.49$. The difference in average pain scores from injections administered to the two different sites was found to be statistically significant $(p<0.05)$. The results supported the hypothesis that intramuscular injections of diclofenac sodium administered to the ventrogluteal site would feel less painful than those administered to the dorsogluteal site.

\section{Key words}

Intramuscular injection, Ventroglueal site, Dorsogluteal site, Pain

\section{Introduction}

Intramuscular injection (IM) is a common practice which causes pain and discomfort to patients ${ }^{[1]}$. Nurses in Turkey tend to use the dorsogluteal site as the first choice for IM injections, despite the fact that this choice of site is ineffective, inappropriate and potentially dangerous. It is accepted that the ventrogluteal site is safer for injections, and causes less pain, because there are no large blood vessels and nerves in the area, and it is distant from bony tissue. This area has the added advantages that the subcutaneous layer here is thin, the necessary position for the patient is easy, and the probability of the medication being delivered to the subcutaneous tissue is low. Although all these superiority of the ventrogluteal site, 
this injection site is not preferred by the nurses in Turkey. Nurses are reluctant to change to the ventrogluteal site for IM injections for a variety of factors. One of the factors is that many nurses think that ventrogluteal site may be more painful for the patient. In addition, although it is reported in the literature that ventrogluteal site causes less pain because there are no large blood vessels and nerves in the area, there is a lack of studies related to the pain intensity in ventrogluteal site.

It is seen that complications arising from intramuscular injections, of which the commonest is pain, are frequent, and are mostly caused by a lack of information and the use of unsuitable techniques ${ }^{[2]}$. Pain arising from this kind of injection generally arises from leakage of the medication and from damage to the subcutaneous tissue ${ }^{[3]}$. Excessive fatty tissue causes the medication not to be absorbed completely, and this causes more pain. For this reason, the use of techniques which reduce leakage of the medication and a suitable injection site will reduce the pain felt during and after intramuscular injection ${ }^{[4]}$. One of these techniques is the choice of a suitable site for the injection such as the ventrogluteal area, which has little subcutaneous fatty tissue ${ }^{[5]}$.

The dorsogluteal area, which is frequently preferred by nurses, has been reported to be the most risky area for intramuscular injection, as it is rich in blood vessels, it is near the sciatic nerve, and the subcutaneous tissue is thicker than in other areas ${ }^{[6]}$. This site often referred to as the upper outer quadrant: the method of dividing the buttock into four equal areas by drawing imaginary lines to bisect it vertically and horizontally has been utilized by many nurses over the years to locate this injection site ${ }^{[2]}$. Craven \& Hirnle ${ }^{[3]}$ suggest that the site is better located by palpating to find the greater trochanter and the posterior iliac spine, then injecting laterally and superior to the midpoint of an imaginary line joining these points. If the injection site is not chosen correctly, very serious complications may result ${ }^{[6,7]}$. It is accepted that the ventrogluteal site is safer for injections, and causes less pain, because there are no large blood vessels and nerves in the area, and it is distant from bony tissue. This area has the added advantages that the subcutaneous layer here is thin, the necessary position for the patient is easy, and the probability of the medication being delivered to the subcutaneous tissue is low ${ }^{[8-10]}$.

Small ${ }^{[7]}$ stated that with intramuscular injections to the dorsogluteal area there was a great likelihood of medication being delivered mistakenly to the subcutaneous tissue, of the medication being insufficiently absorbed, and thus of tissue irritation and pain. In a study by Elizabeth \& Winslow ${ }^{[1]}$, it was shown that in injections to the dorsogluteal area, medication was delivered into fatty tissue. In another study too, it was found that injections to the dorsogluteal area were delivered to the fatty tissue, especially in slightly obese and obese individuals, so that absorption of the drug was low in these individuals and tissue irritation more often resulted ${ }^{[12]}$.

The ventrogluteal site is easily accessible for most patients and located as Kozier, Erb \& Blais ${ }^{[4]}$ suggest, by the nurse placing the heel of his/her opposing hand (i.e. right hand for left hip) on the client's greater trochanter. The index (second) finger of the hand is placed on the client's anterior superior iliac spine and the middle finger stretched dorsally towards but below the iliac crest. The triangle formed by the index finger, the third finger and the crest of the ilium is the injection site. In a study by Covington \& Trattler ${ }^{[13]}$, it was found that the ventrogluteal area was the surest and least painful site for intramuscular injections. Gunes, Zaybak \& Tamsel ${ }^{[14]}$ found that the ventroglueal area could be used safely for intramuscular injections in normal and slightly overweight individuals. In another study, Moharreri et al. ${ }^{[4]}$ recommended the ventrogluteal area for intramuscular injections as it caused relatively less pain and bleeding.

Despite the fact that the ventrogluteal area is identified in the literature as the safest place for intramuscular injection, studies have shown that the vast majority of nurses do not use this area, and show reluctance to change, and although they are aware of the possibility of complications associated with the use of the dorsogluteal area they nevertheless continue to use it ${ }^{[5,9,14]}$. For this reason, it was felt necessary to conduct this study with the aim of pointing out the role of the injection site in the reduction of pain, and of providing data to prove this. 


\section{Methods}

\subsection{Sample}

For this clinical trial, the recruitment of the patients was carried out from January to August 2012 in the state hospital in Bursa located within Turkey's western region. The study participants were those who had been admitted to the hospital, had been diagnosed with spinal intervertebral disc herniation, and had already been prescribed diclofenac sodium by the attending physician to be administered intramuscularly at least every 24 hours; they were 18 years of age or older, had had no pain before the injection and were conscious enough to answer questions about their pain. The reason for the choice of diclofenac sodium in our study was that it was routinely prescribed practice for the patients with disc herniation in the hospital where the study was performed. Because it is very difficult to provide voluntary participation in the studies related to intramuscular injection, we had to choice a routine practice in the hospital. Patients diagnosed with a disease that influenced pain perception such as sensory-motor deficiencies, diabetes, peripheral vascular diseases, peripheral neuropathy and who had illness in their extremities which would prevent them from taking up any required position were excluded from the study.

\subsection{Randomization and intervention}

Between January 21 and August 30, 2012, 128 patients were assessed for eligibility, and 100 were enrolled, but 30 patients were lost to follow-up. The right dorsogluteal and left ventrogluteal sites were used in administering the intramuscular injections. Each injection was randomised to either dorsogluteal site or ventrogluteal site. Two injections were administered to each patient who was blinded to the injection site being administered by the same researcher using two injection sites. The injections were performed with an interval of 24 hours between injections.

Table 1. Intramuscular injection protocol for all participants and techniques

\begin{tabular}{ll}
\hline Diclofenac sodium & $3 \mathrm{ml}$ (a glass ampoule) \\
Syringe size & $5 \mathrm{ml}$ \\
Needle size & 21 gauge \\
Changing needle & two needle technique \\
Air lock & $0.2 \mathrm{ml}$ air lock inserted \\
Site & Right dorsogluteal site and left ventrogluteal site \\
Wipe & $\begin{array}{l}\text { Area cleansed with alcohol and allowed to air dry before needle } \\
\text { insertion }\end{array}$ \\
Insertion angle & $90^{\circ}$ \\
Aspiration & Aspirated \\
Injection duration & $1 \mathrm{ml}$ per 10 seconds \\
Needle withdrawal & At the same angle as insertion \\
After the injection & $\begin{array}{l}\text { Applying a light pressure at the injection site after the injection } \\
\text { and not massaging the site. }\end{array}$ \\
Data recorded & Another investigator assessed pain intensity and recorded. \\
\hline
\end{tabular}

The injection was administered to the dorsogluteal site with the patient in a prone position and the extremities held in a position of internal rotation. The researcher located the dorsogluteal site by drawing an imaginary line from the head of the femur to the posterior superior iliac spine. The injection was delivered into the gluteus maximus at the upper outer portion above the line.

The injection was administered to the ventrogluteal site with the patient in a lateral position, the extremities which were uppermost brought into flexion and the extremities which were below placed forwards. Ventrogluteal site was located by 
putting the palm of her right hand on the left greater trochanter of the patient so that her index finger pointed towards the anterior superior iliac spine. Next, her middle finger was spread to form a "V". The injection was administered into the centre of the "V".

After each injection, the pain felt by the patient during the injection was immediately assessed using VAS by the researcher who was blinded to the injection site being administered. Similar intramuscular injection protocols were administered for all participants. All the injections were administered according to the injection protocol. The protocol was design as listed in Table 1.

\subsection{Instruments}

In data collection, self-administered questionnaire was used. This questionnaire comprised two parts. The first part included items on age, gender, body mass index (BMI) and disease. The second part contained a Visual Analog Scale (VAS) that was used to measure the pain felt by the patient during the intramuscular injection. Immediately following each injection, a VAS were given to the patients and asked to mark a point on the line that best represents their pain at the time of injection. The distance from "no pain" to the patient's mark is then measured in centimetres - this is the VAS score (0-10). Zero represents no pain and 10 represent the worst imaginable pain on this scale. Evidences support that the VAS has a good acceptability, reliability and validity ${ }^{[15,16]}$.

\subsection{Ethical consideration}

The study was approved by ethics committees of Ege University Faculty of Nursing. All participants were informed related to the study before participating, and gave written informed consent before voluntary participation.

\subsection{Data analysis}

Numerical and percentage distribution of sociodemographic data on patients' identification characteristics were calculated. The Wilcoxon signed rank test was used to explore the statistical differences in perceived pain intensity between the two injection sites. Differences in the mean pain intensity at the dorsogluteal and ventrogluteal sites by BMI and gender were analysed using paired $t$ test. The level of significance was set at $p<0.05$.

\section{Results}

Seventy patients were recruited to the study, with ages ranging from 18 to 69 years, mean age 51.5 years ( $\mathrm{SD}=12.4)$. Of the patients, 54\% were female, the mean BMI was $27.1(\mathrm{SD}=4.1)$. All of the patients had disc herniation diagnosis. All patients were alert and conscious enough to answer questions about their pain.

The mean score for perceived pain intensity in ventrogluteal site was $1.24(\mathrm{SD}=1.18)$, the mean score in dorsogluteal site was $1.89(\mathrm{SD}=1.49)$. A Wilcoxon signed-rank test showed that a statistically significant difference was found in mean pain intensity between dorsogluteal and ventrogluteal site $(Z=-2.34, p=0.019)$ (see Figure 1).

Women and men reported significantly lower pain scores in the injections administered to ventrogluteal site. The mean pain score for women was $1.56(\mathrm{SD}=1.13)$ in dorsogluteal site, $1.33(\mathrm{SD}=1.08)$ in ventrogluteal site $(\mathrm{t}=1.99, \mathrm{df}=53$, $p<0.05)$; it was $2.39(\mathrm{SD}=1.83)$ in dorsogluteal site, $1.11(\mathrm{SD}=1.33)$ in ventrogluteal site for men $(\mathrm{t}=2.55, \mathrm{df}=45, p<0.05)$, (see Figure 2).

Figure 3 displays the mean pain intensity at the dorsogluteal and ventrogluteal sites in patients grouped according to BMI as normal weight $\left(18.5-24.9 \mathrm{~kg} / \mathrm{m}^{2}\right)$, overweight $\left(25-29.9 \mathrm{~kg} / \mathrm{m}^{2}\right)$ and obese $\left(>30 \mathrm{~kg} / \mathrm{m}^{2}\right)$ participants. The mean pain intensity for normal patients after IM injection in the dorsogluteal site was $1.75(\mathrm{SD}=1.38)$, it was $1.60(\mathrm{SD}=1.25)$ in ventrogluteal site; for overweight patients it was $1.83(\mathrm{SD}=1.73)$ in the dorsogluteal site, $1.03(\mathrm{SD}=1.13)$ in ventrogluteal 
site; for obese patients it was $2.15(\mathrm{SD}=1.25)$ in dorsogluteal site, $1.12(\mathrm{SD}=1.14)$ in ventrogluteal site. There was a significant difference in pain intensity between dorsogluteal and ventrogluteal site in each BMI group ( $\mathrm{t}=5.05, \mathrm{df}=34$, $p<0.001$ for normal patients; $\mathrm{t}=5.06, \mathrm{df}=31, p<0.001$ for overweight patients; $\mathrm{t}=8.38, \mathrm{df}=32, p<0.001$ for obese patients).

Figure 1. A comparison of the mean perceived pain intensity between dorsogluteal and ventrogluteal site $(p<0.05)$
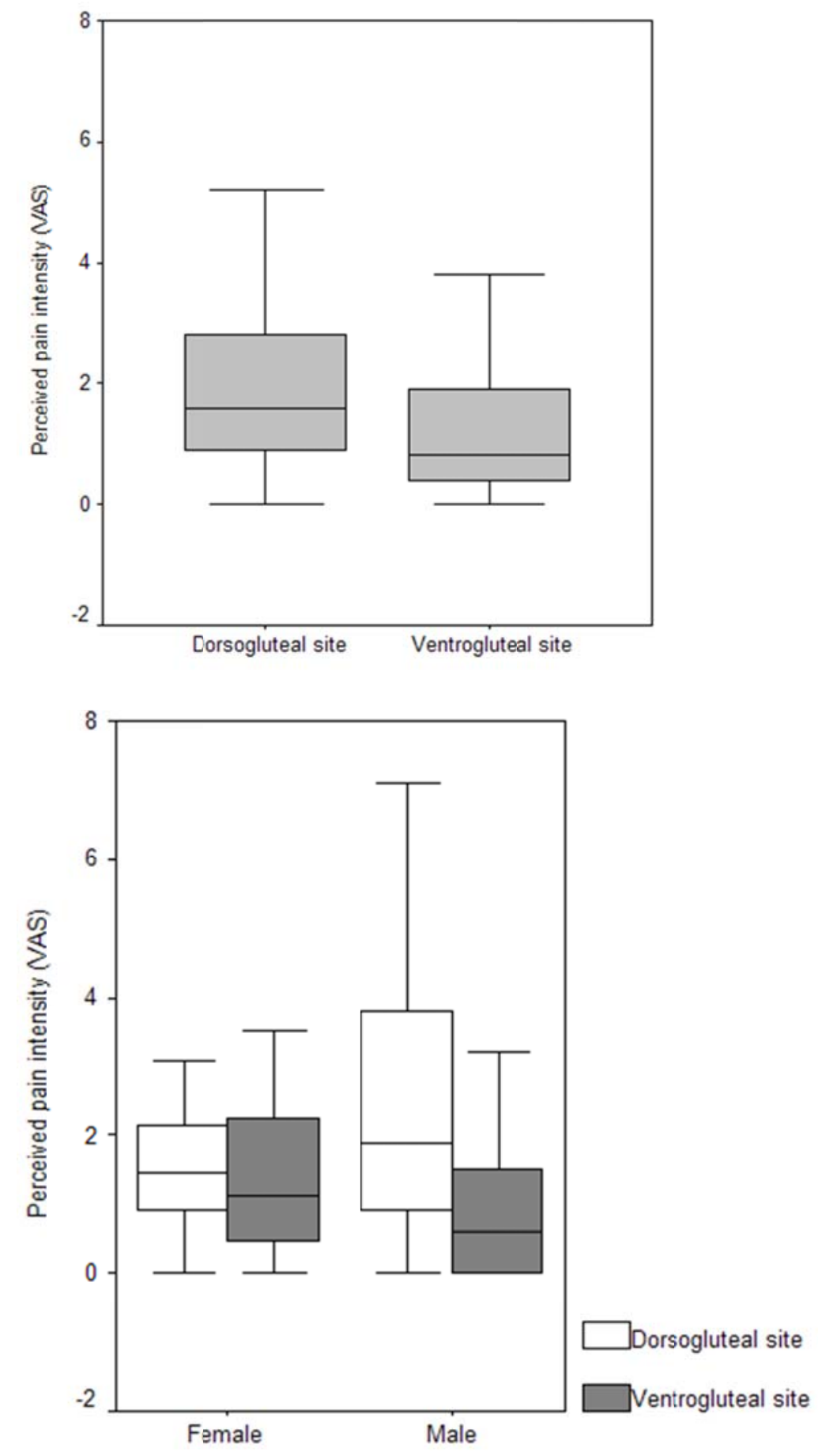

Figure 2. A comparison of the mean perceived pain intensity for males and females in dorsogluteal and ventrogluteal site (all $p<0.05$ )

Female 
Figure 3. A comparison of the mean perceived pain intensity for normal, overweight and obese patients in dorsogluteal and ventrogluteal site (all $p<0.001)$



\section{Discussion}

The findings reveal that the overall pain intensity perceived by the patients was low, with a mean of 1.24 in ventrogluteal site and 1.89 in dorsogluteal site. Even though these results were not clinically worthwhile, the patients felt less pain statistically during intramuscular injections administered to the ventrogluteal site. The literature suggests that the ventrogluteal site should be the primary site for anyone more than seven months of age ${ }^{[17]}$. In the interest of patient safety, the evidence that the dorsogluteal site has several risks associated with it, such as damage to the sciatic nerve, entering the superior gluteal artery and irritation to subcutaneous tissue, cannot be ignored ${ }^{[8]}$. The ventrogluteal site is a safer option which accesses the gluteus medius muscle ${ }^{[21]}$. In the literature, this site is recommended as the primary location for IM injections as it avoids all major nerves and blood vessels and there have been no reported complications ${ }^{[6,7,18]}$. Although there was a small difference between two sites in terms of pain intensity, the ventrogluteal site can be first choice by the nurses when the other advantages of this site are taken into consideration.

The study showed that the injections administered to the dorsogluteal site were more painful in both men and women. These findings of current study are consistent with those of Moharreri et al. ${ }^{[4]}$ and Covington \& Trattler ${ }^{[13]}$ who found that ventrogluteal site is less painful area. However, because Moharreri et al. ${ }^{[4]}$ studied only on male patients, there were no comparative results between men and women in that study. However, in the present study, males reported higher pain intensity than females in dorsogluteal site injections. This finding was not in congruence with the literature. Compared with men, women have more subcutaneous tissue in the buttocks ${ }^{[12]}$. Pain receptors are located within the subcutaneous layer, not in muscle tissue ${ }^{[24]}$. Thus, women consistently report more pain from all intramuscular injections ${ }^{[21]}$. In addition, our results are not supported by Mitchell $\&$ Whitney ${ }^{[25]}$, who asserts that women consistently had higher mean pain scores in intramuscular injection. Therefore, it seems that this finding needs more investigation.

The findings of this study also demonstrated that the perceived pain intensity in dorsogluteal site for overweight (25-29.9 $\left.\mathrm{kg} / \mathrm{m}^{2}\right)$ and obese $\left(>30 \mathrm{~kg} / \mathrm{m}^{2}\right)$ patients were higher than ventrogluteal site. These results may explained by the fact that the ventrogluteal site has less subcutaneous tissue and a thicker muscle mass than the dorsogluteal site ${ }^{[19,20]}$. Therefore, the needle has a better chance of reaching the muscular tissue in the ventrogluteal area than in the dorsogluteal area. In various studies, it was found that most injections given to the dorsogluteal site delivered medication into the fatty tissue ${ }^{[21-23]}$. Pain 
receptors are found within the subcutaneous layer, not in muscle tissues and so injections administered into subcutaneous tissue may be more painful ${ }^{[24]}$. If the needle is not long enough to penetrate through the subcutaneous tissue into the muscle mass, the patient will have more pain, and may develop an abscess or granuloma at the injection site ${ }^{[12]}$.

\section{Conclusion}

The results supported the use of the ventrogluteal site rather than the dorsogluteal site when administering diclofenac sodium injection. The findings demonstrated that pain intensity in intramuscular injections of diclofenac sodium administered to the ventrogluteal site was lower. Although many nurses are reluctant to use the ventrogluteal site for IM injections due to the difficulty of land marking this site and because they think that this site is very painful for the patient, it can be a preferred site by the nurses and the patients for IM injections of diclofenac sodium as it reduced pain and minimized possible complications. It also highlights the need for further research with different medications and with a larger sample including the patients with different diagnosis and all body mass index groups so as to establish the generalizability of the results.

\section{Limitations}

One limitation of our study is that although all the subjects were conscious and did not report any sensory deficits, all patients were diagnosed with intervertebral disc herniation. By potentially affecting sensation, this factor may have affected the results of the study. For this reason, the generalizability of our research findings is limited to similar groups. Secondly, the two injections were administered by the same investigator, so there may be a risk biasing of the results.

\section{References}

[1] Engstrom JL, Giglio NN, Takacs SM, Ellis MC, Cherwenka DI. Procedures used to prepare and administer intramuscular injections: a study of infertility nurses. Journal of Obstetric Gynecologic and Neonatal Nursing. 2000; 29(2): 159-168. PMid:10750682 http://dx.doi.org/10.1111/j.1552-6909.2000.tb02036.x

[2] Newton M, Newton DW, Fudin J. Reviewing the "big three" injection routes. Nursing. 1992; 22(2): 34-41. PMid: 1553072

[3] Cupitt M, Kasipandian V. Pain and intramuscular injections. Anesthesia. 2004; 59(1): 88-99. http://dx.doi.org/10.1111/j.1365-2044.2004.03589.x

[4] Moharreri AR, Nasiri H, Jahanshahi M, Rahmani H, Abdollahi A, Rabiei M. The comparison of pain intensity and rate of bleeding in intramuscular injection in dorsogluteal and ventrogluteal area. Journal of Gorgan University of Medical Sciences. 2007; 9(3): $37-41$.

[5] Greenway K. Using the ventrogluteal site for intramuscular injection. Nursing Standard. 2004; 18(25): 9-42. PMid:15038176

[6] Beyea SC, Nicoll LH. Administration of medications via the intramuscular route: an integrative review of the literature and research-based protocol for the procedure. Applied Nursing Research. 1995; 8(1): 23-33. PMid:7695353 http://dx.doi.org/10.1016/S0897-1897(95)80279-7

[7] Small S. Preventing sciatic nerve injury from intramuscular injections: literature review. Journal of Advanced Nursing. 2004; 47(3): 287-296. PMid:15238123 http://dx.doi.org/10.1111/j.1365-2648.2004.03092.x

[8] Beecroft PC, Redick SA. Clarification of ventrogluteal site. Pediatric Nursing. 1990; 16 (4): 396. PMid:2392350

[9] Donaldson C, Green J. Using the ventrogluteal site for intramuscular injection. Nursing Times. 2005; 101(16): 36-38. PMid: 15871375

[10] Nicoll LH, Hesby A. Intramuscular injection: an integrative research review and guideline for evidence-based practice. Applied Nursing Research. 2002; 15(3): 149-162. PMid:12173166 http://dx.doi.org/10.1053/apnr.2002.34142

[11] Elizabeth H, Winslow RN. The right site for I.M. injections. American Journal of Nursing. 1996; 96(4): 53. PMid:9016086

[12] Zaybak A, Güneş UY, Tamsel S. Does obesity prevent the needle from reaching muscle in intramuscular injections? Journal of Advanced Nursing. 2007; 58(6): 552-556. PMid:17484745 http://dx.doi.org/10.1111/j.1365-2648.2007.04264.x

[13] Covington TP, Trattler MR. Bull's-eye! Finding the right target for I.M. Injections. Nursing. 1997; 27(1): 62-63. PMid:9016086 http://dx.doi.org/10.1097/00152193-199701000-00021 
[14] Güneş UY, Zaybak A, Tamsel S. The Examination of the reliability of the method used in identifying of ventrogluteal site. Journal of Cumhuriyet University School of Nursing. 2008; 12(2): 14-25.

[15] Bijur PE, Latimer CT, Gallagher EJ. Validation of a verball administered numerical rating scale of acute pain for use in the emergency department. Academic Emergency Medicine. 2003; 10(4): 390-392. PMid:12670856 http://dx.doi.org/10.1111/j.1553-2712.2003.tb01355.x

[16] Hollen PJ, Gralla RJ, Kris MG, McCoy S, Donaldson GW, Moinpour CM. A comparison of visual analogue and numerical rating scale formats for the Lung Cancer Symptom Scale (LCSS): does format affect patient ratings of symptoms and qualityof life? Quality of Life Research. 2005; 14(3), 837-847. PMid:16022076

[17] Beyea SC, Nicoll LH. Back to basics. Administering I.M. injections the right way. American Journal of Nursing. 1996; 96(1): 34-35. PMid:8546185

[18] Workman B. Safe injection techniques. Nursing Standard. 1999; 13(39): 47-53. PMid:10497490

[19] Diggle L, Deeks J. Effect of needle length on incidence of local reactions to routine immunisation in infants aged 4 months: randomised controlled trial. British Medical Journal. 2000; 14, 321(7266): 931-933. PMid:11030682 http://dx.doi.org/10.1136/bmj.321.7266.931

[20] Nisbet AC. Intramuscular gluteal injections in the increasingly obese population: retrospective study. British Medical Journal. 2006; 18, 332(7542): 637-638. PMid:16524934 http://dx.doi.org/10.1136/bmj.38706.742731.47

[21] Chan VO, Colville J, Persaud T, Buckley O, Hamilton S, Torreggiani WC. Intramuscular injections into the buttocks: are they truly intramuscular? European Journal of Radiology. 2006; 58(3): 480-484.PMid:16495027 http://dx.doi.org/10.1016/j.ejrad.2006.01.008

[22] Feng WU, Wu YL. Choosing an intramuscular injection needle according to body type. Zhonghua Hu Li Za Zhi. 1994; 5, 29(11): 643-646. PMid:7614580

[23] Morley M, Babiar H. Obesity Prevents Injections from Reaching Muscle[Internet]. 2005[cited 2012 Agust 6]. Available from http:// http://www2.rsna.org/timssnet/media/pressreleases/PDF/pressreleasePDF.cfm?ID=257.

[24] Malkin B. Are techniques used for intramuscular injection based on research evidence? Nursing Times. 2008; 104(50-51): 48-51. PMid:19165987

[25] Mitchell JR, Whitney FW. The effect of injection speed on the perception of intramuscular injection pain. American Association of Occupational Health Nurses Journal. 2001; 49(6): 286-292. PMid:11760527 